precious little book entitled Miner's Companion which is issued by the Prevention of Accidents Committee of the Rand Mutual Assurance Co. It contains vocabularies and sentences in four languages-English, Afrikaans, Sotho, and 'Mine Kaffir'-the last being the common speech. This is of very great interest. Each word and phrase in 'Mine Kaffir', we are told, has been carefully considered by a sub-committee which included a number of Boss Boys. The vocabulary is drawn from English, Afrikaans, and various Bantu languages, and the words are often strangely metamorphosed. 'Hospital' becomes sibedlele; ' mistake', masteki; 'order', odolo; 'loafer', lova; ' washers', amawashar; ' accident', losmesh (smash); 'shelf', ishelufa. Afrikaans words are similarly transmogrified: 'gomlastiek' (rubber), gaskit; ' te betaal' (to pay), batala; ' te mors' (to waste), mosha. 'Padlock' is rendered by kiya; 'putties' by legin; 'power' by stim; 'push' by tshova; 'prison' by jele. Some words bear more than one meaning, e.g. skelem is both 'scoundrel' and 'misfire'; mali, ' rate', 'wage', 'reef'; layini, 'string', 'line', 'pile'. In this variety of 'Kitchen Kaffir' there are naturally a large number of technical mining terms mostly adapted from English: tshafu, 'shaft'; mtshini, 'rock-drill'; smok, 'compressed air'; stiksayid, 'pillar'; loskwer, 'face '; qala lo hol, 'collar the hole '; jompolo, ' jumper'. The Bantu concords disappear. Where any prefixes remain they are used quite indiscriminately: zonke is 'all' whatever noun it may be attached to; so with munye, 'another'; mangaki? 'how many?'; maningi, 'many'; everything big is makulu. Ka is the invariable genitive particle: 10 foloman $k$ a lo sayinete, 'the cyanide works' manager'; 10 mlungu ka lo gesi, 'the electrician'; shap ka lo smit, ' the smith's shop '; lo tshif ka wena, 'your shift'. $L_{0}$ is the article. The personal pronouns are reduced to four: mina, 'I'; wena, 'thou'; tina, 'we'; yena, 'he', 'you', 'they'. 'You will get me into trouble' is translated yena faka mina lo trabul. Sometimes the perfect suffix -ile appears but as a rule verbs are used only in the stem-form. The future and potential are made by means of yazi; yazi fika, "he may, can, or will come'. The universal negative is hayi generally used with kona, ' here ': hayi kona is ' no' and also ' he must not', 'you must not', ' he does not', 'you do not'; hayi kona vuma, 'he does not agree, he refuses'; hayi kona stim is the equivalent of 'weak'; and yena kona lo lak, 'lucky'. The Miner's Companion has been compiled 'in order to assist European employees in the early days of their mine employment in overcoming the diffculty of making themselves understood by native labourers'. This seems to imply that the labourets know the lingo; indeed it is stated that 'Mine Kaffir' is a dialect understood by the majority of natives on the Witwaterstand gold-mines. It would be interesting to know how raw tecruits acquire it and how long it takes them to do so,

\title{
A Beit Research Fellowship in Southern Rhodesia
}

ON representations by the Federation of African Welfare Societies in Southern Rhodesia and with the full support of the Southern Rhodesia Government, the Beit Trustees have generously agreed to provide the necessary funds for the appointment of a Research Fellow to undertake economic and social research among Africans in Southern Rhodesia, with special reference to problems of urbanization. The appointment will be for a period of three years. The work will be under the guidance and control of the Natal University College with the assistance of the Federation of African Welfare Societies in Southern Rhodesia.

\section{$V I^{m e}$ Session du Congrès Colonial National en Belgique}

SELON une heureuse tradition le Congrès Colonial National se réunit tous les cinq ans. Le dernier congrès ayant tenu ses assises à quelques jours près de l'invasion, fin avril 1940, le $\mathrm{vI}^{\mathrm{me}}$ congrès aurait dû avoir lieu régulièrement en I945. Les événements de la guerre 
imposèrent au comité organisateur d'attendre que la liaison avec la colonie fût devenue plus normale. Après une série de prises de contact au cours des années i 945 et I 946 , il fut décidé que les travaux du prochain congrès seraient consacrés à l'étude de 'la question sociale indigène', et la date en fut fixée au 4 et $s$ octobre 1947 . Le congrès vient donc d'avoir lieu. A la séance inaugurale, M. le Ministre des Colonies annonça la dotation d'une somme de 2 milliards 350 millions au fonds du bien-être indigène. Ce fonds, qui permettra des dépenses annuelles d'un quart de milliard, aura pour mission d'aider matériellement, socialement et spirituellement les populations de l'intérieur; celles des centres extracoutumiers et des camps miniers étant confiées, sous la surveillance de l'État, à la responsabilité des employeurs.

Les rapports, présentés et discutés au congrès, furent l'œuvre de diverses commissions, présidées par des personnalités coloniales éminentes. Elles furent au nombre de dix, ayant respectivement comme objet: l'enseignement à tous les degrés pour indigènes, l'hygiène et la démographie, l'artisanat indigène, les cultures indigènes, les organisations sociales de chefferies, la main-d'œuvre indigène, l'organisation familiale, les évolués, le rôle social de la force publique. M. Max Horn, conseiller du gouvernement de la colonie, s'était chargé de coordonner les conclusions générales.

Nous ne pouvons songer à analyser chacun de ces rapports. Louons-en, dans l'ensemble, l'excellente venue, le sens de la réalité, le vif désir de progrès.

\section{Institut pour la Recherche scientifique en Afrique centrale}

PAR un arrêté en date du I juillet, x947, a été créé un institut pour la recherche scientifique en Afrique centrale, ayant pour l'objet de promouvoir, réaliser at coordonner, spécialement au Congo Belge et au Ruanda-Urundi, l'étude de l'homme et de la nature. A cette fin, il sera créé au Congo Belge et à Ruanda-Urundi un ou plusieurs centres où les chercheurs belges et étrangers pourront s'adonner à leurs études. L'Institut sera administré par un conseil composé de personnalités scientifiques belges et étrangers.

\section{Language Problems in Fundamental Education}

Nine experts (British, French, Belgian, American, Dutch, Czech) were summoned to Paris in July I 947 by U.N.E.S.C.O. to advise on the following questions : (I) How far are small tribal languages capable of serving the needs of modern education? (2) If the mother tongue must be used for the early teaching of children can a second language be taught at a later stage to break down the barriers of language difficulties? (3) How can the latest techniques of teaching languages with the aid of films and gramophone records be applied to fundamental education projects?

\section{Fundamental Education and the Use of the Cinema}

The British Film Institute organized a Conference on 'The Film in Colonial Development" on 16 January 1948. The Conference was opened by the Secretary of State for the Colonies and among the speakers was Mr. John Grierson, Director of Mass Communications in U.N.E.S.C.O. Mr. Grierson described the peoples of the world as being on the movementally and spiritually; as being in revolt against illiteracy and primitive conditions; this was a challenge to every citizen, especially to those of Great Britain (and other nations) who possessed the privilege and responsibility of governing colonial peoples. The present problem was itself the result of the world's riches and of the gap between technical invention and the knowledge of how to use it. He quoted the words of Julian Huxley: 'Man 